\title{
Replanting the Flower in Different Soil? A Critical Analysis of Education Borrowing in Hong Kong
}

\author{
Anthony Chow ${ }^{1, *}$ \\ ${ }^{1}$ Graduate School of Education, Faculty of Social Sciences and Law, University of Bristol, \\ Bristol, United Kingdom \\ *Correspondence: Graduate School of Education, Faculty of Social Sciences and Law, \\ University of Bristol, Bristol, United Kingdom. E-mail: achow@live.hk
}

Received: May 7, 2014

Accepted: May 24, $2014 \quad$ Published: June 16, 2014

doi:10.5296/ije.v6i2.5815

URL: http://dx.doi.org/10.5296/ije.v6i2.5815

\begin{abstract}
This paper critically analyses the impact the New Senior Secondary (NSS) has had on Hong Kong through Phillips and Ochs' four-stage model of policy borrowing in education. It argues that the Hong Kong government overlooked the fundamental contextual differences between the two curricula, and that this incompatibility has led to various challenges in integrating the NSS into the existing education system. This paper also contributes to the methodological literature on comparative education and theorisation of education borrowing by illustrating the importance of context. The monopolistic and generalisation assumptions in the positivist paradigm have misled many governments to reify statistics and uncritically transfer incompatible policies to their home countries; the case of the NSS in Hong Kong is an example of this. Although the interpretivist paradigm helps comparativists better understand local context, it is also important to be aware of the limitations of the analytical model used here. Phillips and Ochs' model was developed based on observations of education borrowing between England and Germany, and it might not truly represent the situation in non-English speaking Asian countries. Also, the model was not specifically built for a capitalist economy, and, therefore, comparativists also need to be aware of the economic structure of the country they are studying, as this can greatly affect the aim of public education. Further study should incorporate literatures and models from Asian countries in order to make the analysis more relevant.
\end{abstract}

Keywords: education borrowing, comparative education, comparative research, school curriculum, policy transfer 


\section{Introduction}

Many schools in Hong Kong criticise the New Senior Secondary (NSS) school curriculum for borrowing the form of the International Baccalaureate Diploma Programme curriculum (IBDP) without retaining its substance. According to a local survey, over 90 percent of students and 63 percent of school principals said that the NSS was even more stressful for them than the former curriculum (文匯報, 2013). At the same time, schools also reported that the government underestimates the standard number of teaching hours by 37 percent, and that in reality students need to spend an average of 10 hours in school every day to complete the curriculum (Yeung, 2013; 大公報, 2012). The new curriculum was supposedly meant to reduce stress and make teaching more effective, but the NSS does not seem to be achieving its goals. What went wrong with this education borrowing?

The fundamental concept of the NSS was borrowed from the popular IBDP, but these two curricula were developed according to different contextual requirements and have different goals. This paper critically analyses the impact the NSS has had on Hong Kong through Phillips and Ochs' four-stage model of policy borrowing in education. It argues that the Hong Kong government overlooked the fundamental contextual differences between the two curricula, and that this incompatibility has led to various challenges in integrating the NSS into the existing education system.

\section{The New Senior Secondary School Curriculum in Hong Kong}

Many local educationalists believe that the NSS concept originated from the internationally recognised IBDP, which is offered by the International Baccalaureate Organization (劉美顔, 2009; 東方日報, 2006). Similarities between NSS and IBDP have been found in at least five areas, including overall aim, teaching style, curriculum structure, assessment methods, and subject requirements (Cheung, 2010; EMB, 2004). This section provides a concise introduction to this curriculum and discusses contextual factors which relate to the policy borrowing decision.

The NSS curriculum was launched in 2009 to replace the secondary school system that had been used since 1974 in British colonial Hong Kong. The former system was an elitist educational system in which only the top 30 percent of students were promoted to the matriculation years and the remaining 70 percent were diverted to a vocational training path or left school to join the workforce (Choi, 1999). In NSS, all students are expected to complete the shortened matriculation curriculum as a strategy to increase Hong Kong's overall competitiveness in the knowledge economy.

NSS is part of the public education system and is tasked with serving diverse groups of local students regardless of their social or economic status. It is a "broader, more balanced education-for-all” curriculum (HKEAA, 2013, p. 7). Politically, the NSS is also a part of the larger decolonisation moment aimed at removing British influence from Hong Kong's 
educational system (Hung, 2013). Since the handover of sovereignty to China in 1997, many efforts at decolonisation have been initiated. For instance, the government launched new subjects such as Mandarin Chinese and, more controversially, changed the language of instruction from English to Cantonese. The government has said that the NSS adopts the "best practices" from various education systems with modification to fit local needs (EMB, 2004, p. 17).

IBDP, in contrast, is an internationally recognised senior secondary school curriculum designed to prepare students for entry into universities. It was developed in the mid-1960s by a group of international educators for students in capitalist economies who needed a transferable mobilised curriculum between countries. These students were children of diplomats and international workers and wanted to pursue an internationalised curriculum instead of the one available in the country in which they lived (Bray \& Yamato, 2003).

\section{Theoretical Framework on Education Borrowing}

Zymek and Zymek (2004, p. 25) argue that many education polices are not new innovations, but are intentionally borrowed from other countries. Education borrowing is an important area of study in the field of comparative and international education. Policymakers often borrow successful education policies or practices from other countries to solve problems in their home countries.

Phillips and Ochs (2004, p. 774) describe education borrowing as a "conscious adoption in one context of policy observed in another”, and Powell and Di Maggio (1991) note that education borrowing is attractive to policymakers because it can reduce the risk and uncertainty of creating a brand new policy. There are four major goals of education borrowing: solving internal problems (Rose, 1991), minimising the uncertainty of new policies (Nedergaard, 2006), delivering political actions (Dolowitz \& Medearis, 2009), and seeking assistance (Steiner - Khamsi, 2006). The NSS borrowing in Hong Kong had all four goals.

\subsection{Historical Background of Education Borrowing}

The history of education borrowing can be traced back to the 18th century, when Marc-Antoine Jullien categorised and analysed a large-scale dataset to describe an educational system and subsequently developed guidelines for other researchers on his scientific comparative model (Crossley \& Broadfoot, 1992). The main aim of this model was to better understand foreign education systems and search for "best practices". The positivist methodology thereafter gained much support and was preferred for such comparisons. Comparativists in the positivist camp, such as Jullien, Cousin and Mann, created guidelines for comparing education systems, and later interpretive comparativists such as Phillips, Ochs and Schriewer further conceptualised and theorised the sub-field of education policy borrowing.

The first serious discussions of education borrowing emerged during the 20th century as a 
result of globalisation (Dolowitz \& Marsh, 1996). Interpretive comparativists believe positivist methodology suffers from an insufficient understanding of context (Crossley \& Jarvis, 2001) and a lack of local applicability (Ochs \& Phillips, 2004). This is a significant methodological gap overlooked by positivist researchers. Crossley (2001) adds that comparativists have to be critical when assessing foreign education systems and to consider their limitations from theoretical, contextual and cultural dimensions.

\subsection{Paradigm Shift - Scientific to Context-Sensitive}

Debate continues about the most suitable methodological approach to comparative research on education borrowing. Scientific methods used by positivists still hold a dominant place in comparative education, with findings often presented in the form of league tables or lists of "best practices". There are many advantages of employing a positivist methodology, and it has attracted many comparativists and policymakers, especially those who are searching for “quick fixes” (Slee \& Weiner, 2001).

Nevertheless, a great deal of literature in the field points to the methodological limitations of the positivist approach and the potential problems it can cause (Crossley \& Jarvis, 2001). Stenhouse (1979, pp. 5-6) argues that comparative research should provide "insight rather than law as a basis for understanding", and that these insights should be used to "tutor our judgement" when we borrow policies from other countries. Many distinguished comparativists have long argued that there are major problems with any simplistic uncritical transfer of educational policy and practice from one social-cultural context to another (Crossley \& Jarvis, 2001). Distinguished comparativist Michael Sadler gave a seminal lecture in 1900, in which he said:

"We cannot wander at pleasure among the educational systems of the world, like a child strolling through a garden, and pick off a flower from one bush and some leaves from another, and then expect that if we stick what we have gathered into the soil at home, we shall have a living plant” (as quoted in Bereday, 1964, p. 310).

The famous quote marks the clear beginning of a revolutionary paradigm shift in the field. Sadler pointed out that a policy considered "best" in one country might not work in another country because of contextual differences. Yang (2007, p. 258), in support of Sadler, writes that positivist approaches lacked a regard for the importance of historical context, social conditions and the deep structures of social relations in comparative research. In his lecture, Sadler urges comparativists to pay closer attention to differences in political-legal, economic, social-cultural and technological factors between countries, and to use interpretivist methodologies to understand meanings and values within a local context.

\section{Phillips and Ochs' Model of Policy Borrowing in Education}

Like Sadler, Ochs and Phillips (2002, p. 331) argue that one cannot ignore "the conditions that have created the need to look to examples 'elsewhere' and the suitability of the 'home' conditions for particular kinds of educational transfer from such examples from 'elsewhere'”. 


\section{Macrothink}

"Context matters" (Crossley \& Jarvis, 2001), because it sets the conditions for education borrowing and gives comparativists a clearer lens through which to appraise the complexity and suitability of such decisions.

Ochs and Phillips (2002, p. 457) stress that contextual factors influence policy borrowing decisions and affect the policy development and implementation process. They created a four-stage context-driven analytical model of policy borrowing in education, shown in Figure 1 below (2003).

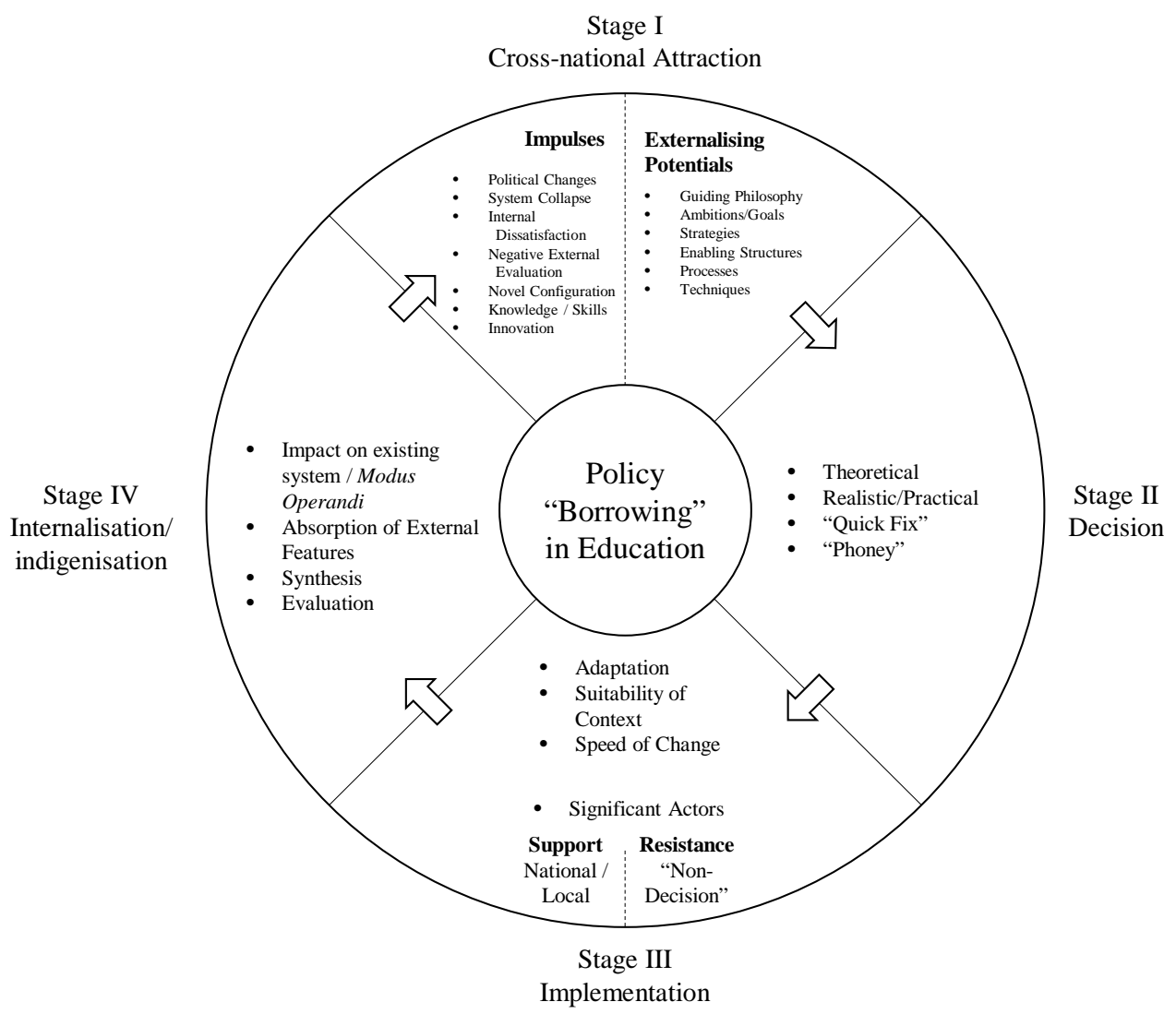

Figure 1. Phillips and Ochs'(2003) four-stage context-driven analytical model of policy borrowing in education

The first stage is Cross-national Attraction, which examines the antecedents that foster policy-borrowing decisions and categorises them into impulses and externalising potentials (Phillips and Ochs (2003, p. 30). Impulses are internal preconditions that attract policy changes. Stimulating factors could be internal dissatisfaction, system collapse, or simply political changes. Externalising potentials are external stimuli that encourage change, such as ambitions, goals or new skill requirements.

The second stage is decision. Phillips and Ochs (2003, p. 31) divided decision-making into four categories: theoretical, realistic/practical, "quick fix", and "phoney". Theoretical decisions occur when the government makes policy decisions that are so abstract that they cannot be easily implemented in the home country. Realistic/practical refers to decisions which are made after assessing the critical success factors; the main considerations in making 
these decisions are feasibility and instantaneity. "Quick fix” refers to a decision made to solve an urgent problem. However, this is risky, and the policy borrowed may not be compatible with the home context. Finally, "phoney" refers to a borrowing decision made instantly, without thorough consideration. Questions have been raised about the practicability and sustainability of such borrowing decisions, as most "phoney" decisions are made for political reasons.

The third stage is implementation. This refers to the adaptation process, the suitability of the context, and support or resistance from various policy actors (Phillips \& Ochs, 2003, p. 32).

The final stage is internalisation and indigenisation. This refers assessing the impact of a policy in a new context by re-assessing the original motives and objectives, compatibility in the home context, and synergy with the system. It also involves reflecting on and evaluating the entire borrowing exercise (Phillips \& Ochs, 2003, p. 32).

\subsection{Critical Evaluation of the Model}

Despite its strengths, this model has not escaped criticism from scholars, policymakers and practitioners. It has a logical and sequential structure built on an assumption that the policy process is liner, rational, and top-down, and that a one-size-fits-all mechanism works in most cases. Black (2001) argues that this approach tends to overlook the fact that the policy process can be random, and decisions are often made in ambiguous environments involving multiple actors with different viewpoints and incentives. Many other policy analysis models are designed to tackle these challenges, such as Kingdon's Multiple Stream Framework cited in (cited in Zahariadis, 1999).

Another flaw is that the model makes no distinction between developing and developed countries, which may have total different social ideologies. As Steiner-Khamsi (2006, p. 675) and Tikly (2001) pointed out, the key problem with most comparative studies is that they are biased toward the developed world, and their models are of limited relevance to developing countries. The Phillips and Ochs model would have been much more complete if the authors had included a more in-depth discussion of the implications of economic and political factors in addition to social-cultural factors.

The model also relies too heavily on historical information. It stresses analysing past events and learning from prior failures (Rose, 1991), but it does not provide any suggestions for improvements in future borrowing decisions. An analytical lens should provide a forward-looking mechanism so that policymakers can understand the potential consequences of their decisions. The model would be more useful if it could envisage the dynamic between contextual factors and potential policy outcomes.

There have been few scholarly attempts to theorise a framework for education borrowing, and Phillips and Ochs' model is one of the only models that is context-sensitive and provides a holistic and cyclical view of the entire process. However, the model also overemphasises the cross-national attraction stage, while there is not as much depth of research in the other three stages (楊啟光, 2009). Other models in the field of public policy or sociology may also provide information that can fill these theoretical gaps. 
Despite these flaws, Phillips and Ochs' four-stage model is still a useful theoretical framework to analyse the NSS case in this paper for three major reasons. First, its context-sensitive interpretivist approach can detect incompatibilities between the borrowed policy and the home country, and it fills the methodological gaps neglected by the positivist approach. Second, the NSS reform was a pre-planned, top-down policy, which fulfils the assumptions of this model. Third, the reform was a rational policy-borrowing process with clear aims and objectives.

\section{Critical Analysis of Hong Kong's NSS Curriculum Policy Reform}

This section critically evaluates the impact of the NSS policy on Hong Kong by applying Phillips and Ochs' four-stage model of policy borrowing in education.

\subsection{Stage One: Cross-National Attraction}

Political imperatives and internal dissatisfaction were the two major impulses that prompted the Hong Kong government to change its education policy. Hong Kong was a British colony, and its former educational curriculum had a strong British imprint. Lin and Martin (2005) found that decolonisation is a widespread drive for policy change in many post-colonial countries, with educational system and official language the most commonly changed elements. Since the sovereignty of Hong Kong was transferred to China in 1997, the Chinese Central Government had a motive to replace these foreign ideologies and increase citizens' national consciousness as part of the decolonisation process (黃庭康, 2002).

The elitism of the former system had also been producing many undesirable consequences. Under the former curriculum, students needed to write two public exams in four years, and only the top 20 percent of them would be admitted to university (Kung, 2012). Students faced huge stress and pressure, as these exams were the only pathway for university admission. A local survey found that 21 percent of senior secondary school students reported suicidal ideation or suicide attempts due to exam stress (HKJC, 2001). The government admitted the former curriculum put an "over-emphasis on examinations" and created unnecessary stress for students (EMB, 2004, p. 3). Schools argued that the government should introduce a more pluralistic education system to cater to diverse learning styles, and overhaul the curriculum to encourage all students to reach their full potential (Forlin, 2007).

Globalisation is the most significant externalising potential that encourages education borrowing (Crossley, 2008). Evidence shows that the Hong Kong government has a tendency to borrow "best education practices" from abroad, such as commoditising the higher education sector and introducing an associate's degree system. These are indicators of increased connection with the globalised world. As IBDP is the most successful globalised curriculum recognised by many top universities (Cambridge \& Thompson, 2004), it is natural that this model would attract the interest of the Hong Kong government.

However, many scholars warn that there are also downsides to this kind of borrowing. Ball (1998) finds that although external potentials provide the impetus for policy borrowing, 
resistance often arises when these potentials react with contextual factors.

\subsection{Stage Two: Decision}

Phillips and Ochs (1994) define decision as the process by which a country determines the feasibility of implementing a model policy from another country at home. A significant amount of research shows that a borrowed policy has a higher chance of failure if that policy's original goal is different from the goal set in the home country (Dolowitz, 1998; Evans \& Davies, 1999). As such, the government has to thoroughly evaluate the nature and content of a policy before deciding whether to borrow it.

This paper argues that the decision to borrow the IBDP concept was problematic for three reasons: conflicting goals, inaccurately prioritised local requirements, and insufficient support.

First, the decision to borrow the IBDP curriculum was unwarranted, as it conflicts with the fundamental aim of public education. Olaniyan and Okemakinde (2008) suggest that, according to human capital theory, the aim of public education is to provide educational opportunities to all citizens with the ultimate goal of improving the productivity of society. IBDP is not designed for public education and does not bear any national responsibilities. Its main aim is to prepare students for universities (Peterson, 2003).

The NSS concept overlooks its public responsibility, aiming to prepare students for universities while downplaying the importance of vocational training. As a consequence, the Hong Kong Report of Population Policy (2013) has pointed out Hong Kong will face a shortage of 22,000 skilled technicians in 2018; most of these positions require technical qualifications instead of academic degrees. Psacharopoulos (1987, p. 187) found from his empirical research that although the cost of running vocational programmes is considerably higher than that of academic programmes, the associated benefits increase at a comparable rate. Many studies have showed that early streaming is far more effective arrangement in manpower planning (Hippach-Schneider, Krause, \& Woll, 2007; Tilak, 2002). As the NSS overlooks the need of vocational education, it has worsened the local manpower shortage. Again, the creation of the NSS decision ignored local context and blindly borrowed an incompatible policy that has weakened public education.

Second, the government inaccurately gauged local requirements. Hong Kong government has launched a series of education reform initiatives in the last decade, from the administrative structure to the curriculum organisation (Cheng, 2009). The previously imposed policy decisions created ripple effects, and schools in Hong Kong asked the government for time to fully integrate all the previous policy changes before launching the NSS. Over 10,000 teachers and parents held a large-scale protest against the unwelcomed policy changes in 2006 (蘋果日報, 2006). This was an early warning signal to the government that the series of reforms had created unmanageable pressures for teachers and students and priority should be given to the internalisation of the previous policies. Rose (1993, pp. 132-134) claims that the possibility of policy transfer depends on the perceived side-effects. Wolman (1993, p. 42) has 
showed that existing policy commitments can constrain the policy borrowing process even if the government and the public share the same ideological goals. Continuous policy reform led to poor morale among teachers and many emotional and health problems. Despite these concerns, the government went ahead with the launch of the NSS, although there were an increasing number of IBDP providers in the private sector and no evidence to show that the NSS was urgently needed.

Third, the government provided insufficient support for teacher training and school development. All current teachers were trained based on the former curriculum, which focused on specialist subject knowledge rather than transferable skills. There was no guarantee that all of these teachers would be capable of delivering the NSS without retraining. Chrysostomou (2004) found that an important prerequisite for any education borrowing is teacher preparation and training. With insufficient training and development support, the Hong Kong government's borrowing decision is problematic.

In this case, the government adopted a top-down approach and neglected warning signs from stakeholders. Public opinion can have a crucial impact on how policy is decided. Kingdon (1984) suggested in his multiple stream framework that a successful policy is constructed by a consolidation of factors coming from multiple directions. It is dangerous for the government to make a policy decision alone and ignore feedback from other stakeholders.

\subsection{Stage Three: Implementation}

The implementation of NSS would have been more effective if the government had appointed an experienced project leader, and refrained from miscommunication to the public. Many scholars argue that leadership style and relevant experience are as important as policy decisions in the implementation phrase (Costello, 1970; Sabatier \& Mazmanian, 1980). The NSS policy has been developed across three generations of local government since 2000. The official in the current government who is responsible for the policy's implementation is Eddie Ng Hak-kim, the secretary for education. Perhaps the most serious disadvantage at this stage is that Mr. Ng does not have relevant experience in policy implementation. The public has questioned his ability to execute such complex policy reform with a lack of experience in public policy or knowledge of the local education sector (Chong, 2012). Harchar, Trahan, and Broussard (2011, p. 331) stress that an experienced project leader is crucial to policy implementation, as the leader must have the ability the deal with the contingencies and turn around. Studies have shown that the government underestimated the number of class hours the NSS would require by almost 40 percent, and students need to study over 10 hours per day in order to cover the entire curriculum (Yeung, 2013). The government also underestimated teaching hours by 37 percent. This has led to a serious misallocation of resources and put enormous pressure on schools (大公報, 2012).

The government also miscommunicated with the public about a concept it called "Happy Learning”, creating inaccurate expectations of the NSS. This miscommunication has led to resistance in the implementation phrase. All the advertisement or promotion focused on it is a less stressful curriculum so that students can focus on learning rather than memorising. However, the message is not aligned to the actual situation and many students found the NSS 
made them more stress than the former curriculum as the government significantly miscalculate the teaching hours.

This miscommunication gave rise to inaccurate expectations in schools. Wallner (2008) found in her research that miscommunication does not normally happen if the relationship between the government and school is positive, and Lee, Strohmeier, Bunker, and Van Orden (2008) write that "miscommunications can lead to unnecessary media hysteria and public alarm". In a recent local survey, as many as 63 percent of school principals said there was a large difference between the government's promises about the NSS and the actual curriculum, and they did not agree that students were happy throughout the NSS learning process (星島日報, 2013). This miscommunication has led to a large gap in expectations and created frustration among students

The resistance to the NSS that has arisen shows that the policy was not thoroughly reviewed and tested for adaptability and suitability to local context. The implementation would have been more successful if the government had included a simulation run before the actual launch.

\subsection{Stage Four: Internalisation and Indigenisation}

This paper argues that the NSS policy has had a significant impact on the existing system on both the policy and the curriculum level.

At the policy level, schools recognise the importance of the NSS "Education For All" concept. However, the actual curriculum was not built to accommodate educational diversity. The unrealistic workload and difficult course content favour elite students over their less academically-gifted counterparts (Yeung, 2013). Since NSS combines two levels of the former curriculum, the learning needs of the students are now more diverse, as classes include students who, under the former curriculum, would not have qualified for further study. Given the same time and resources, teachers can only focus on teaching rather than helping students in need. This shows another incompatibility of the IBDP curriculum in a public education context and creates many challenges in the internalisation process. Many problems have surfaced in the internalisation stage, as the NSS is not fully delivering its original goals.

Many scholars argued that insufficient attention to differences in social and ideological context between the borrowing country and the home country may eventually lead to policy failure (Dolowitz \& Marsh, 2000, p. 17; James \& Lodge, 2003). The government should consider widening alternative pathways to foster educational diversity and provide different types of manpower to society.

At the curriculum level, the new School Based Assessment (SBA) has attracted much resistance from schools because it puts further pressure on teachers and students. SBA is a school-administered assessment which aims to "enables students to achieve their best in a more relaxed and familiar setting” (HKEAA, 2012, p. 1). The original intention of the SBA was to reduce the stress of taking public exams so that students with different styles of learning would not be disadvantaged. While the original intention behind the SBA was good, 90 percent of NSS students said the SBA made them feel very stressful, and over 50 percent 
of students said the SBA did not help them grasp knowledge of the subject being assessed (文 匯報, 2013). This unexpected deviation can be traced back to the overall setup of the IBDP project, which is a group project and emphasizes critical thinking skills and awareness of social issues. In contrast, the SBA is an individual assignment which focuses on subject knowledge. While the effectiveness of the SBA has yet to be seen, it has pushed students' workload and stress to a historical high. It will take time for NSS to be fully integrated into the education system, as a deep-rooted culture cannot be changed in one day. Levin (1998, p. 139) explains that resistance to education policy change is normal and the "take-up of any education policy idea depends greatly on the political and social environment". The Hong Kong government should, as Phillips and Ochs (2004) suggested, continuously reflect and evaluate the situation against the original policy goal and make correction if necessary.

\section{Implications}

Phillips and Ochs' (2003) model is a comprehensive framework for analysing NSS education borrowing in Hong Kong. Its context-sensitive nature contributes to a better understanding of the borrowing process and reveals many important factors that explain the challenges and resistance the borrowed policy faces. This paper argues that the government has borrowed the superficial form of the model policy without its substance. The analysis above shows there are many areas in which the borrowed policy conflicts with the local context, from policy goals to actual implementation.

Simply "replanting the flower in different soil" is not sufficient. The government needs to reassess the local context and make adjustments to the NSS. In addition to the policy's content, leadership, budget, and support from stakeholders are also critical to the policy's success. The top-down policy approach needs to be reviewed, as feedback received from schools is equally important. Finally, education borrowing from a commercialised education source must be assessed thoroughly, as often the model policy is designed for a specific group of students.

\section{Conclusion}

This evaluation is written from a practitioner-scholar perspective, and it contributes to strengthening research capacity on education borrowing in Hong Kong. It identifies contentions and challenges in each of the borrowing stages and recommends potential improvements for further policy borrowings.

This paper also contributes to the methodological literature on comparative education and theorisation of education borrowing by illustrating the importance of context. The monopolistic and generalisation assumptions in the positivist paradigm have misled many governments to reify statistics and uncritically transfer incompatible policies to their home countries; the case of the NSS in Hong Kong is an example of this. Although the interpretivist paradigm helps comparativists better understand local context, it is also important to be aware 
of the limitations of the analytical model used here.

Phillips and Ochs' model was developed based on observations of education borrowing between England and Germany, and it might not truly represent the situation in non-English speaking Asian countries. Also, the model was not specifically built for a capitalist economy, and, therefore, comparativists also need to be aware of the economic structure of the country they are studying, as this can greatly affect the aim of public education. Further study should incorporate literatures and models from Asian countries in order to make the analysis more relevant.

\section{References}

Ball, S. (1998). Big policies/small world: An introduction to international perspectives in education policy. Comparative Education, 34(2), 119-130. http://dx.doi.org/10.1080/03050069828225

Bereday, G. (1964). Sir Michael Sadler's" Study of Foreign Systems of Education". Comparative education review, 7(3), 307-314. http://dx.doi.org/10.1086/445012

Black, N. (2001). Evidence based policy: proceed with care. BMJ: British Medical Journal, 323(7307), 275. http://dx.doi.org/10.1136/bmj.323.7307.275

Bray, M., \& Yamato, Y. (2003). Comparative education in a microcosm: Methodological insights from the international schools sector in Hong Kong. In Comparative Education 49(1-2), (pp. 51-73): Springer. http://dx.doi.org/10.1007/978-94-007-1094-8

Cambridge, J., \& Thompson, J. (2004). Internationalism and globalization as contexts for international education. Compare, 34(2), 161-175. http://dx.doi.org/10.1080/0305792042000213994

Cheng, Y. (2009). Hong Kong educational reforms in the last decade: Reform syndrome and new developments. International Journal of Educational Management, 23(1), 65-86. http://dx.doi.org/10.1108/09513540910926439

Cheung, K. W. (2010). Overview of the New Academic Structure and New Senior Secondary Curriculum. Hong Kong: Hong Kong Examinations and Assessment Authority.

Choi, C. C. (1999). Public examinations in Hong Kong. Assessment in Education: Principles, Policy \& Practice, 6(3), 405-417.

Chong, D. (2012, 27 August). Education Secretary Eddie Ng Hak-kim faces a hard political lesson, Scouth China Morning Post. Retrieved from http://www.scmp.com/news/hong-kong/article/1022947/education-secretary-eddie-ng-ha k-kim-faces-hard-political-lesson

Chrysostomou, S. (2004). Interdisciplinary approaches in the new curriculum in Greece: A focus on music education. Arts Education Policy Review, 105(5), 23-30. 
http://dx.doi.org/10.3200/AEPR.105.5.23-30

Costello, T. W. (1970). Psychological aspects: the soft side of policy formation. Policy Sciences, 1(1), 161-168. http://dx.doi.org/10.1007/BF00145202

Crossley, M. (2001). Cross-cultural issues, small states and research: capacity building in Belize. International Journal of Educational Development, 21(3), 217-229. http://dx.doi.org/10.1016/S0738-0593(00)00030-4

Crossley, M. (2008). International transfer and comparative education. Comparative Education, 44(1), 1-2. http://dx.doi.org/10.1080/03050060701809359

Crossley, M., \& Broadfoot, P. (1992). Comparative and international research in education: scope, problems and potential. British Educational Research Journal, 18(2), 99-112. http://dx.doi.org/10.1080/0141192920180201

Crossley, M., \& Jarvis, P. (2001). Context matters. Comparative Education, 37(4), 405-408. http://dx.doi.org/10.1080/03050060120091210

Dolowitz, D. (1998). Learning from America: Policy transfer and the development of the British workfare state. Oregon: Sussex Academic Press.

Dolowitz, D., \& Marsh, D. (1996). Who learns what from whom: a review of the policy $\begin{array}{llll}\text { transfer literature. } \quad \text { Political } & \text { 343-357. }\end{array}$ http://dx.doi.org/10.1111/j.1467-9248.1996.tb00334.x

Dolowitz, D., \& Marsh, D. (2000). Learning from abroad: The role of policy transfer in $\begin{array}{llll}\text { contemporary } \quad \text { policy-making. } \quad \text { Governance, } & \text { 13(1), }\end{array}$ http://dx.doi.org/10.1111/0952-1895.00121

Dolowitz, D., \& Medearis, D. (2009). Considerations of the obstacles and opportunities to formalizing cross-national policy transfer to the United States: a case study of the transfer of urban environmental and planning policies from Germany. Environment and planning. C, Government \& policy, 27(4), 684. http://dx.doi.org/10.1068/c0865j

EMB. (2004). Consultation Paper - Reforming the Academic Structure of Senior Secondary Education and Higher Education. Hong Kong: Retrieved from http://www.legco.gov.hk/yr04-05/english/panels/ed/papers/ed1029cb2-90-1e.pdf.

Evans, M., \& Davies, J. (1999). Understanding policy transfer: A Multi-level, multidisciplinary perspective. Public administration, 77(2), 361-385. http://dx.doi.org/10.1111/1467-9299.00158

Forlin, C. (2007). Inclusive educational practices: A way forward for Hong Kong. Chinese Education \& Society, 40(4), 63-75. http://dx.doi.org/10.2753/CED1061-1932400405

Harchar, R., Trahan, M., \& Broussard, J. (2011). Blazing a New Trail for the Educational Turnaround Leader. Lancaster, Pennsylvania: DEStech Publications, Inc.

Hippach-Schneider, U., Krause, M., \& Woll, C. (2007). Vocational education and training in 
Germany: short description.

HKEAA. (2012). Hong Kong Diploma of Secondary Education Examination - Information on School-based Assessment. Hong Kong: Hong Kng Examinations and Assessment Authority.

HKEAA. (2013). The New Senior Secondary Learning Journey - Moving Forward to Excel. Hong Kong: Education Bureau, Hong Kong SAR Retrieved from http://334.edb.hkedcity.net/doc/eng/FullReport.pdf.

HKJC. (2001). Suicidality among Secondary School Students in Hong Kong. Retrieved 25 October, 2013, from http://csrp.hku.hk/WEB/eng/pageHandler.asp?id=148

HKSAR. (2013). Report of the Task Force on Population Policy. Hong Kong: Government of Hong Kong SAR.

Hung, S. (2013). Civic Education Policy of the Hong Kong’s Special Administration Region: a Historical and Comparative Analysis with Theories of the State. Asian Education and Development Studies, 2(2), 6-6. http://dx.doi.org/10.1108/20463161311321448

James, O., \& Lodge, M. (2003). The limitations of 'policy transfer'and 'lesson drawing'for public policy research. Political studies review, 1(2), 179-193. http://dx.doi.org/10.1111/1478-9299.t01-1-00003

Kingdon, J. (1984). Agendas, Alternatives, and Public Policies. Boston: Little, Brown and Company.

Kung, J. (2012). Principal Speech on Annual Benediction Ceremony. Retrieved 25 October, 2013, from http://www.stc.edu.hk/home/profile/principal.asp?id=1195

Lee, R., Strohmeier, B., Bunker, K., \& Van Orden, D. (2008). Naturally occurring asbestos-A recurring public policy challenge. Journal of Hazardous Materials, 153(1), 1-21. http://dx.doi.org/10.1016/j.jhazmat.2007.11.079

Levin, B. (1998). An epidemic of education policy:(what) can we learn from each other? Comparative Education, 34(2), 131-141. http://dx.doi.org/10.1080/03050069828234

Lin, A., \& Martin, P. (Eds.). (2005). From a Critical Deconstruction Paradigm to a Critical Construction Paradigm: An introduction to Decolonisation, Globalisation and Language-in-Education Policy and Practice. Canada: Multilingual Matters Ltd.

Nedergaard, P. (2006). Which countries learn from which? A comparative analysis of the direction of mutual learning processes within the open method of coordination committees of the European Union and among the Nordic countries. Cooperation and Conflict, 41(4), 422-442. http://dx.doi.org/10.1177/0010836706069870

Ochs, K., \& Phillips, D. (2002). Comparative studies and'cross-national attraction'in education: a typology for the analysis of English interest in educational policy and provision in Germany. Educational studies, 28(4), 325-339. http://dx.doi.org/10.1080/0305569022000042372 
Ochs, K., \& Phillips, D. (2004). Processes of educational borrowing in historical context. Educational policy borrowing: Historical perspectives, 7-23.

Olaniyan, D., \& Okemakinde, T. (2008). Human capital theory: Implications for educational development. Pakistan Journal of Social Sciences, 5(5), 479-483.

Peterson, A. D. C. (2003). Schools across frontiers: The story of the International Baccalaureate and the United World Colleges: Open Court Publishing.

Phillips, D., \& Ochs, K. (2003). Processes of policy borrowing in education: Some explanatory and analytical devices. Comparative Education, 39(4), 451-461. http://dx.doi.org/10.1080/0305006032000162020

Phillips, D., \& Ochs, K. (2004). Researching policy borrowing: some methodological challenges in comparative education. British Educational Research Journal, 30(6), 773-784. http://dx.doi.org/10.1080/0141192042000279495

Powell, W., \& Di Maggio, P. (Eds.). (1991). Introduction. Chicago: University of Chicago Press Chicago.

Psacharopoulos, G. (1987). To vocationalize or not to vocationalize? That is the curriculum question. International Review of Education, 33(2), 187-211. http://dx.doi.org/10.1007/BF00598482

Rose, R. (1991). What is Lesson-drawing. Journal of public policy, 11(1), 1-22. http://dx.doi.org/10.1017/S0143814X00004918

Rose, R. (1993). Lesson-drawing in public policy: A guide to learning across time and space: Cambridge Univ Press.

Sabatier, P., \& Mazmanian, D. (1980). The Implementation of Public Policy: A Framework of Analysis. Policy Studies Journal, 8(4), 538-560. http://dx.doi.org/10.1111/j.1541-0072.1980.tb01266.x

Slee, R., \& Weiner, G. (2001). Education reform and reconstruction as a challenge to research genres: Reconsidering school effectiveness research and inclusive schooling. School Effectiveness and School Improvement, 12(1), 83-98. http://dx.doi.org/10.1076/sesi.12.1.83.3463

Steiner-Khamsi, G. (2006). The economics of policy borrowing and lending: A study of late adopters. $\quad$ Oxford Review of Education, 32(5), 665-678. http://dx.doi.org/10.1080/03054980600976353

Stenhouse, L. (1979). Case Study in Comparative Education: Particularity and Generalisation. Comparative Education, 15(1), 5-10. http://dx.doi.org/10.1080/0305006790150102

Tikly, L. (2001). Globalisation and education in the postcolonial world: Towards a conceptual framework. Comparative Education, 37(2), 151-171. http://dx.doi.org/10.1080/03050060124481 
Tilak, J. (2002). Vocational education and training in Asia. The handbook on educational research in the Asia-Pacific region.

Wallner, J. (2008). Legitimacy and public policy: Seeing beyond effectiveness, efficiency, and performance. Policy Studies Journal, 36(3), 421-443.

Wolman, H. (Ed.). (1993). Cross-National Comparisons of urban Economic Programs: Is Policy Transfer Possible? New York: St. Martin's Press.

Yang, R. (2007). Comparing education policies. In M. Bray, B. Adamson \& M. Mason (Eds.), Comparative Education Research: Approaches and Methodology (pp. 241-262). Hong Kong: The Comparative Education Research Centre, University of Hong Kong and Springer.

Yeung, L. (2013, 23 September). Pressure points, Scout China Morning Post. Retrieved from http://www.www.scmp.com/lifestyle/family-education/article/1315786/pressure-points

Zahariadis, N. (1999). Ambiguity, time, and multiple streams. Theories of the policy process, 73-93.

Zymek, B., \& Zymek, R. (2004). Traditional-National-International. Explaining the Inconsistency of Educational Borrowers.

劉美顏. (2009, 25 May). 直資名校逐個數：宏信書院 IB 課程 培養學生國際視野, 文匯 報. Retrieved from http://paper.wenweipo.com/2009/05/25/ED0905250017.htm

大公報. (2012，26 November). 學界促分拆「企會財科」，大公報. Retrieved from http://www.takungpao.com.hk/paper/content/2012-11/26/content_1391781.htm

文匯報。(2013，15 July). 校本評核需改善，文匯報。 Retrieved from http://paper.wenweipo.com/2013/07/15/WW1307150002.htm

星島日報. (2013, 26 June). 新高中愉快學習 63\%校長不認司, 星島日報. Retrieved from http://www.singtao.com/yesterday/edu/0626go01.html

東方日報. (2006，1 October). 直資校辦 IB 課創新路, 東方日報. Retrieved from http://orientaldaily.on.cc/archive/20061001/new/new_k1cnt.html

楊啓光. (2009). 全球化進程中的國際教育政策轉移. 比较教育咑究, 12, 80-85.

蘋果日報. (2006, 23 January). 反教改高呼「羅太下台」 逾萬教師遊行, 蘋果日報. Retrieved from http://hk.apple.nextmedia.com/news/art/20060123/5596969 
黃庭康. (2002). 國家權力形構與華文學校課程改革-戰後新加坡及香港的個案比較. 教 育與社會咑究(4), 111-133.

\section{Copyright Disclaimer}

Copyright reserved by the author(s).

This article is an open-access article distributed under the terms and conditions of the Creative Commons Attribution license (http://creativecommons.org/licenses/by/3.0/). 